\title{
FÁBULAS DOMESTICADAS: O PAPEL POLÍTICO E MORAL DA ESCOLA NAS ADAPTAÇÕES DIDÁTICAS DO TEXTO LITERÁRIO
}

Flávia Amparo

\section{RESUMO}

De que maneira as fábulas de autores como Esopo e La Fontaine foram sofrendo adaptaçóes no decorrer do tempo até se configurarem como modelo moralizante para crianças nos manuais didáticos do séc. XIX? Esse trabalho pretende analisar o processo de adaptaçáo da fábula para fins didáticos e a obra "O filho do elefante", de Kipling, como uma forma de refletir sobre as tensôes da criança diante da temática da violência e do autoritarismo do universo adulto.

PALAVRAS-CHAVE: fábula; Kipling; adaptação.

"Eu preparo uma canção/ que faça acordar os homens/e adormecer as crianças." (ANDRADE, 2005, p. 188)

\section{Introdução}

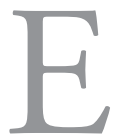

m 1668, Jean de La Fontaine publicou seu famoso livro intitulado Fables Choisies, cujas 124 fábulas, retiradas da tradição literária e transpostas em versos, dividiam-se em seis partes pelos dois volumes publicados da obra. Posteriormente, o escritor haveria de ampliar essa primeira edição, acrescentando novas fábulas, até a última edição em vida do autor, de 1693. É interessante observar que as fábulas de La Fontaine, apesar do sentido moralizante, não apresentavam uma lição moral transcrita, como se convencionou a usar em algumas traduçóes posteriores do autor e dos demais fabulistas clássicos. 
No Brasil do séc. XVIII, no auge da exploração do ouro nas Minas Gerais, a obra do escritor francês chegou a ser proibida, fazendo parte da lista de livros defesos que eram impedidos por Portugal de entrarem na Colônia. Mas o que tornava um livro povoado de animais falantes, obra de pura imaginação, um instrumento tão perigoso nas mãos dos leitores da Colônia?

Logo nas primeiras páginas das Fables, La Fontaine nos revela a natureza essencial de suas histórias: "L'apparence en est puérile, je le confesse; mais ces puérilités servent d'enveloppes a des vérités importantes" [A aparência é infantil, admito; mas estas puerilidades são o invólucro de importantes verdades] (La Fontaine, 1818, p. 2). As fábulas, portanto, apesar da aura pueril, traziam reflexóes sobre os comportamentos, discursos e ideias do mundo dos homens, levando o leitor a pensar sobre questóes relevantes. De certo modo, a própria autoridade dos discursos era questionada nos versos das fábulas de La Fontaine, na medida em que a inteligência dos fracos parecia ser mais eficaz que a força dos poderosos.

O tema da opressáo dos povos seria ilustrado em muitas fábulas do escritor francês, como em "O lobo e o cão”. Na história, confrontando o lobo faminto ao cão robusto e saudável, La Fontaine revela os meandros da dominação dos homens, que alimentam o cão com os seus sobejos, mantendo-o forte, mas o privam da liberdade, submetendo-o aos seus caprichos e, principalmente, à coleira.

A tirania dos homens não é revelada pelo discurso do cão - que apresenta apenas o lado promissor da sua aliança com os humanos -, mas pela observação do lobo, que percebe a ausência de pelos no pescoço do outro, indício que denuncia o seu cativeiro. Diante de tal constatação, o lobo prefere continuar sua jornada, ainda que solitário e faminto, recusando-se a vender a sua liberdade por algumas migalhas diárias: "Tanto importa, que eu, desses teus sobejos,/ Nem provar quero / A preço tal. Adeus." (LA FONTAINE, 1815, p. 11).

O epílogo da história não se configura como moral, mas como reflexão acerca da proposta de vida, aparentemente promissora, do cão. É o leitor que pode ou não tirar para si um aforismo que, nesse caso, poderia ser: "melhor o bocado com liberdade, do que a fartura com opressão", desfecho que revela a inconformidade diante das estratégias de dominação. 
Retomando a afirmação de La Fontaine anteriormente citada, podemos concluir que o fabulista não compôs essas histórias apenas para servir de lição ou de lazer às crianças. A contundência de determinadas reflexôes, comprovada pela proibição da obra de La Fontaine em Portugal e na sua Colônia, não se encontra na lição moral que, virtualmente, lhe poderia servir de desfecho, como costumamos ressaltar no estudo desse gênero textual. É o desnudamento de certos discursos velados, aparentemente repletos de vantagens, que nos interessa, uma vez que escondem certas estratégias de dominação do outro. Vide o exemplo do lobo e do cão: libertar-se de um jugo exigia, primeiramente, o reconhecimento de que nenhuma vantagem, por mais promissora que fosse, poderia ser admitida em troca da liberdade.

É interessante como a fábula passa a ganhar novos contornos e aplicaçóes de acordo com o tempo. Afora as cristianizaçóes que durante a Idade Média sofreram as fábulas gregas e romanas, as traduções de Esopo dos séculos XVIII e XIX, em Portugal, passaram a trazer aplicaçôes morais, com a finalidade de direcionar a leitura de cada fábula. Não bastava, nesse caso, uma mera lição como desfecho da narrativa, mas toda uma explicação do seu conteúdo, buscando extrair a moral ali contida e direcionar o leitor para uma dada interpretação.

Numa das ediçóes portuguesas da obra de Esopo, de 1848, a aplicação moral feita a partir da fábula "O lobo e o cão" dissimula o tema da liberdade, na medida em que prefere sublinhar a diferença entre os bens do trabalho (lobo) e os males do ócio (cão).

Tangenciando o tema da fábula, o editor da obra portuguesa destaca o trabalho como ferramenta de dignidade, sendo, portanto, a escolha dos que optam pela liberdade, ainda que à custa de fome e privação. $\mathrm{O}$ destaque do assunto revela uma ideologia essencialmente burguesa, adequada aos moldes de produção da época. Apesar de o nome de Esopo figurar na capa, o verdadeiro autor da moralidade se dissimula no discurso do outro.

Não há prata nem ouro por que deva vender-se a liberdade, e quem a estima no que ela merece, faz o que fez esse lobo, que escolhe antes trabalho e fome que perdê-la: mas comedores 
negligentes e apoucados não estimam ser livres, contanto que comam o pão ociosos, e os tais são significados nesta fábula pelo cấo. (ESOPO, 1848, p. 68)

Outras ediçôes portuguesas mais antigas, que datam de 1791, já traduziam Esopo inserindo no texto as aplicações morais. No prefácio dessas obras, vemos que há uma intenção de dissuadir a leitura de outras fábulas e autores que poderiam perverter a boa educação moral e religiosa, talvez uma referência a certos livros proibidos pela Real Mesa Censória, na época, como os de La Fontaine.

Para os censores, a retomada da leitura de um clássico grego, como Esopo, só era válida pelo crivo ético, com a aplicação explícita das moralidades, a fim de direcionar o pensamento dos leitores e de formar "o juízo e os costumes dos meninos", conforme vemos em Vidigueira (1791). Ao contrário de fazer da fábula o invólucro de importantes verdades, conforme apregoava La Fontaine, há um franco interesse em extrair e apontar as verdades de uma maneira explícita para os leitores, de modo que a leitura não sugerisse nenhum sentido dúbio ou permitisse outra margem de interpretação.

São repreensíveis, e indignas de estarem contadas no número de obras, aquelas composiçôes, onde se não descortina a moral, como um tecido de ridicularias sem ordem, nem método, homens voando, e estátuas falando. Semelhantes assuntos não se devem consentir na República das letras; não emendam os costumes, antes os corrompem, pervertem a Religião, em lugar de a fazer mais respeitada, e venerada. Deste gênero de escritos temos nós na nossa língua um sem número deles. (...) As Fábulas de Esopo têm na verdade muito merecimento, servem de grande utilidade para a mocidade, para todos; porque bebendo estes contos com o leite, criam na alma sentimentos honrados, ideias grandes, conhecimento de si mesmo, do que são e do que podem vir a ser: são como uns espelhos, em que compóe as suas ações. São finalmente as Fábulas aquelas que ensinam a formar o juízo, e os costumes dos meninos. (VIDIGUEIRA, 1791, p. iv-viii) 
No século XIX, surge também uma nova forma de diluir as fábulas de La Fontaine e de outros autores indesejáveis no lugar de definitivamente proibi-las. A ideia foi concebê-las não mais como uma leitura "para todos", como vimos do prefácio de Vidigueira, mas unicamente como histórias infantis, buscando adaptá-las especificamente para este público. Assumindo um papel didático, as fábulas receberam, além das traduçôes moralizantes, uma série de simplificações para compor as chamadas "leituras escolares". Sendo incorporadas aos manuais e livros didáticos, foram perdendo pouco a pouco a reflexão original e adquirindo a estrutura adequada, segundo a época, à instrução dos pequenos.

Ao analisar a leitura na escola, Teresa Colomer (2007) revela o papel que alguns planos educativos vão conceder à literatura, em especial, no século XIX, tentando adequá-la a um perfil didático com a finalidade de instruir crianças e jovens leitores. As adaptaçooes de modelos e clássicos literários tornaram-se, portanto, importantes instrumentos de moralização e de padronização do comportamento das crianças.

Durante séculos a literatura exerceu um papel preponderante como eixo vertebral do ensino linguístico, a formação moral, a consciência de uma cultura com raízes clássicas greco-latinas e, desde o séc. XIX, de aglutinação de cada nacionalidade. Que a literatura tivesse representado todas essas funçôes não significa, no entanto, que os alunos tenham se dedicado a ler obras literárias nas aulas, nem que a literatura lida fosse adequada à sua capacidade e interesse. Basta lembrar que, segundo os redatores do Plano Educativo de 1825, na Espanha, as únicas leituras necessárias na escola primária eram a cartilha, o catecismo e as Fábulas de Samariego (sic), e que, um século mais tarde, passou a ser obrigatória uma leitura tão discutível para destinatários infantis como o Quixote. (COLOMER, 2007, p. 15)

É muito relevante o destaque dado pelo Plano Educativo hispânico aos três elementos essenciais da educação primária: cartilha, catecismo e Fábulas de Samaniego. Esses elementos, essenciais na educação tradicional e confessional, conjugavam os valores caros à sociedade, que a escola pretendia repro- 
duzir e compartilhar entre seus discípulos. À cartilha mecânica e repetitiva, que se particularizava numa leitura restrita de mundo, se agregava o livro de catecismo (que difundia os valores religiosos) e a leitura das fábulas moralizantes (que ratificavam os comportamentos moralmente aceitos e adequados à sociedade). A alfabetização, tarefa da Escola, estava associada a um modelo de leitura adequado à Igreja e ao Estado, e não ao desfrute do indivíduo ou à sua capacidade de reflexão sobre a literatura. A criança era ensinada a não questionar nenhum dos valores vigentes na sociedade, sendo, portanto, treinada a repeti-los à exaustão até absorvê-los inteiramente.

Fica bem nítida a transformação que a escola efetuará nesse gênero textual, ao transpor as fábulas de Esopo e de La Fontaine para uma realidade didática. Basta ler a obra citada por Colomer, as Fábulas de Samaniego, para notar as principais modificações ocorridas nessa transição. Já no prefácio de seu livro, Samaniego revela que a obra é uma encomenda de uma instituição tradicional da Espanha e que sua finalidade é estritamente moral e didática. Em especial, destaca o "zelo patriótico" do Diretor da instituição como atributo básico à formação da nacionalidade, essencial à sociedade no séc. XIX.

Com efeito, o Diretor da Real Sociedade Bascongada, vendo a educação como a base em que se estriba a felicidade pública, emprega a maior parte do seu zelo patriótico no cuidado de proporcionar aos jovens alunos do Real Seminário Bascongado tudo quanto pode conduzi-los à instrução; e sendo, por assim dizer, o primeiro alimento com que se deve nutrir o espírito das crianças as máximas morais, disfarçadas com o agradável artifício da fábula, me desafiou a pôr uma coleção delas em verso castelhano, com o objetivo de que recebessem esta instrução, embora não como se mamassem no seio materno, conforme o desejo de Platão, mas pelo menos antes de chegar ao estado de poderem entender o latim. (SAMANIEGO, 1781, p. xiv)

$\mathrm{Na}$ afirmação do autor espanhol vê-se, logo de início, a mudança do princípio original do prefácio das Fábulas, de La Fontaine. Não há mais o propósito de "revelar as verdades aos homens"; a Samaniego importam as máximas morais, que se disfarçam no "artifício das fábulas", usadas unicamente para "nutrir o 
espírito das crianças”. Desse modo, as releituras didáticas acabaram optando pelo lugar comum, pelas fórmulas e frases feitas, esvaziando as fábulas originais de certa esperteza discursiva que propunha um diálogo implícito com o leitor.

Como exemplo, podemos citar uma fábula de Samaniego intitulada "El Lobo y el Perro flaco" [O lobo e o cão fraco]. Vemos claramente que o autor se inspirou nas fábulas de Esopo e de La Fontaine aqui citadas. Porém, já não é mais o lobo quem está faminto, mas o cão, que, fraco e desnutrido, se vê aprisionado pelo oponente. Diante do fato, o débil animal pede ao lobo uma segunda chance, afirmando que dali a quinze dias iria participar de um banquete e, assim sendo, o adversário poderia desfrutar de sua carne mais fartamente.

Vencido o prazo, o lobo vai cobrar a promessa, mas encontra o cão com um companheiro de peso, um mastim feroz de nome "Matalobos". Logicamente, o lobo sai com o rabo entre as pernas concluindo: "Pernas pra que vos quero!/ Até as crianças sabem/ que é de melhor valia/ um pássaro na mão/ do que cem voando." (SAMANIEGO, 1781, p. 179).

O aspecto moral da história ganha destaque, uma vez que aponta para o domínio dos fortes sobre os mais fracos: o lobo deveria ter aproveitado enquanto o cão estava indefeso, em vez de esperar por uma possibilidade vaga no futuro. Permitiu, assim, que este se fortalecesse e fizesse alianças poderosas que o tornaram invencível. Conforme o ditado apregoado na fábula adaptada, "é melhor um pássaro na mão do que cem voando", a moral absorvida parece dar azo ao oportunismo pernicioso.

O cão, sendo o mais fraco, não vence o outro apenas pelo discurso, mas pela força de um terceiro, que neutraliza o poder do inimigo em comum. É interessante perceber também que há certa identificação do provável interlocutor dessas histórias, quando o autor diz que: "Até as crianças sabem". Nesse caso, o lobo chega a uma constatação óbvia e pueril, que não mais exige o perfil de observador atilado, diluindo, portanto, uma das características mais marcantes desse personagem na constituição das fábulas clássicas: a esperteza.

Samaniego reconhece que fez uso de uma ampla licença autoral ao modificar o conteúdo das histórias originais, mas sequer mantém o que afirma ser o "cerne do apólogo", ou seja, o princípio ou a ideia central da fábula tomada como mote. O autor espanhol se apropria apenas dos contextos locais, dos personagens e de alguns detalhes do texto original para formular as suas máximas moralizantes: "removendo, adicionando ou mudando", diz ele, 
mas podemos considerar os três movimentos, numa disposição tão constante quanto concomitante, e não "rara vez", como chega a afirmar. E, por fim, para completar o trabalho, o autor ainda cria uma falácia argumentativa, ao destacar que houve uma falta de escrúpulos dos fabulistas, uma vez que se apropriaram da obra dos antecessores e efetuaram uma série de modificaçôes. Se as obras imortais fizeram isso, por que não a dele?

Com todas as dificuldades que tive para seguir com a formulação de minha pequena obra a partir desses fabulistas, e o exemplo que achei no último, me resolvi a escrever tomando por modelo os argumentos de Esopo, destacando-os como se fossem de alguns modernos (...) senão ainda variando rara vez algum tanto, seja no argumento, seja na aplicação da moralidade: removendo, adicionando ou mudando alguma coisa, que, sem mexer no cerne do apólogo, contribuísse a dar-lhe certo ar de novidade e graça.

É verdade que, conforme a minha consciência, mais de quatro vezes se peca nesse método contra os preceitos da fábula; mas esta licença é tão recorrente entre os fabulistas que, qualquer um que se disponha a cotejar uma mesma fábula em diferentes versôes a encontrará tão transformada em cada uma delas em relação ao original, que, degenerando gradativamente numa e noutra versão, virá a parecer-lhe diferente em cada uma delas. Se com todas essas licenças ou pecados contras as leis da fábula existiram fabulistas que fizeram sua carreira chegar ao templo da imortalidade, por que teria eu escrúpulos que eles não tiveram? (SAMANIEGO, 1781, p. xi)

Logicamente, o diálogo com uma tradição anterior foi um recurso muito usado pelos fabulistas. La Fontaine, por exemplo, bebeu nas fontes de Esopo e Fedro, mas não construiu a sua obra à sombra daqueles. Acrescentou seu próprio estilo, escolheu o verso para compor os seus textos e conseguiu renovar a tradição das fábulas a partir de um novo olhar, que pressupunha uma releitura do seu próprio tempo e das questóes vigentes na sociedade. 
Samaniego opta pela adaptação das fábulas com o propósito de "facilitar" a leitura desses textos pelos jovens leitores e de simplificar algumas passagens que ele considerava incompatíveis com a inteligência infantil. $\mathrm{O}$ olhar que lança às obras do passado não é de alguém que se propóe a dialogar com uma tradição, mas de quem procura corrigi-la de seus aparentes "desvios" ou "defeitos". Mais uma vez, para justificar seu projeto edificante, apropria-se de uma argumentação falaciosa, ao destacar que, segundo certo crítico da época (autor de um “Tratado de educação"), só cinco ou seis fábulas de La Fontaine possuíam uma simplicidade infantil. Logo, justifica a importância de seu projeto como uma forma de aperfeiçoar a "falha" apontada na obra.

Samaniego atribui a si um papel que La Fontaine jamais havia pensado para um fabulista: servir de filtro ou de tradutor de determinadas leituras a fim de adequá-las à compreensão infantil.

Empreguei nimiamente minha atenção a fazer versos fáceis para adaptá-los, segundo o meu entender, à compreensão dos jovens. Que em alguns momentos pareça meu estilo não apenas simples, senão raso, é ruim; mas não seria muitíssimo pior que, fazendo-os incompreensíveis às crianças, ocupassem essas sua memória com inúteis versos? Apesar de certo pesar nessa parte, acredito que tenha conseguido atingir a minha finalidade. Um autor moderno, em seu Tratado de educação, disse que em toda a coleção de La Fontaine não reconhece senão cinco ou seis fábulas "em que brilha com eminência a simplicidade infantil", e ainda analisando algumas delas, encontra passagens inadequadas à inteligência das crianças. (SAMANIEGO, 1781, p. xii)

Diante do discurso do autor, verificamos que muitas das transposiçóes didáticas de certos clássicos, senão a maioria, afetaram o cerne das ideias das obras originais. Sob a aparente proposta de simplificação da linguagem para adequá-la à criança, havia um desejo de apagar os "desvios" de pensamento e de controlar as ideias que poderiam ser revolucionárias e subversivas, portanto, não adequadas à educação dos comportamentos do indivíduo na escola e, quiçá, fora dela. Em vez de coibir a leitura de certos livros, como Portugal fez no séc. XVIII para controlar ideais revolucionários, a escola do séc. XIX adota 
um viés mais sutil de dominação: transforma os clássicos literários em obras infantis e didáticas com fins moralizantes.

\section{Em busca da fábula perdida}

Harold Bloom, em 2003, levou a cabo uma proposta de construir uma coletânea que valorizasse os clássicos da literatura e que os tornasse acessíveis às crianças e aos jovens leitores: Os contos e poemas para crianças extremamente inteligentes de todas as idades. A proposta de Bloom não foi "facilitar" a linguagem a partir de adaptaçóes dos clássicos, mas de selecionar poemas, contos e fragmentos de romances de autores importantes de língua inglesa que pudessem ser acessíveis não apenas para as crianças, como também para o leitor de "todas as idades". De certo modo, Bloom dá um enfoque especial às obras que marcaram a infância de muitos leitores e que podiam ser redescobertas em outras fases da vida, sem nenhuma puerilidade.

Dentre os autores selecionados por Bloom, dois deles representam uma retomada da fábula em seu viés original, uma vez que, sob o invólucro pueril, conseguiam guardar importantes reflexões a respeito do mundo dos homens: Lewis Carroll e Rudyard Kipling. Os dois autores do século XIX foram contemporâneos e escreveram seus textos tendo como fundamento o universo infantil, mas não se restringiram a simplificações. Suas obras, até hoje, conseguem conquistar um público de idade variada.

O mais interessante em "A história da Falsaruga", de Alice no país das maravilhas, e "O filho do elefante", de Histórias simplesmente, que correspondem respectivamente a algumas das fábulas de Carroll e Kipling selecionadas na coletânea de Harold Bloom, é que em ambas aparecem personagens que representam o mundo infantil. Tanto Alice quanto o elefantinho ilustram o perfil questionador da criança, que sempre examina e contesta os saberes consolidados do universo adulto. De igual modo, os dois protagonistas são criticados pelos outros personagens, e até punidos, por possuírem uma "curiosidade insaciável”. As indagaçóes de ambos os personagens são a tônica das histórias e, por conta dessa curiosidade, precisam efetuar uma longa jornada não só em busca de respostas, mas também de autoconhecimento.

Outro detalhe que nos chama a atenção é o ponto de vista adotado por cada autor, em especial quando refletem sobre a forma como a sociedade passa 
a oprimir os indivíduos, especialmente as crianças, com suas regras e cerceamentos. Parece que há todo um esforço do sistema social em calar a voz infantil e submetê-la à alienação vigente no mundo adulto.

Enquanto Carroll questiona os rígidos padrôes da educação inglesa na era vitoriana, Kipling escolhe como ambientes especiais de suas fábulas a Índia e a África, com suas paisagens e animais exóticos, embora sejam também espaços marcados pela opressão do imperialismo inglês. $\mathrm{O}$ universo animal composto por Kipling não segue a dinâmica de um mundo natural e harmônico, mas surge como espaço de violência e de disputa por poder, como um possível espelhamento das lutas entre dominadores e dominados da vida real.

Em "A história da falsaruga" (The Mock-Turtle's Story) e "O filho do elefante" (The Elephant's Child), há uma crítica aos modelos educacionais vigentes na época, tanto aqueles que eram adotados na escola quanto os assimilados no seio familiar. Infelizmente, muitos desses modelos permanecem na sociedade atual.

No texto de Carroll, já na abordagem inicial, temos a incômoda presença da Duquesa, personagem especializada em extrair liçóes morais de cada frase pronunciada por Alice e em deturpar os sentidos da conversa, impossibilitando o diálogo. Não há como deixar de fazer referência às aplicações morais comumente encontradas nos manuais escolares, que, ao procurarem extrair liçóes, acabavam deturpando o sentido primordial dos textos em nome de propósitos aparentemente instrutivos.

A "falsa tartaruga", por sua vez, apresenta a Alice a sua "Escola do Mar" e desconstrói os nomes das disciplinas do currículo escolar ao introduzir conteúdos estranhos na grade, como: Lavagem, Patim e Grogue, Tintura a Olho, Mistória antiga e Desdenho, que são uma espécie de pastiche de disciplinas do currículo da época (Linguagem, Latim e Grego, Pintura a Óleo, História antiga e Desenho). A cada surpresa de Alice, a Falsaruga recrimina sua falta de conhecimento, obrigando a menina a saber de assuntos que escapam à sua realidade cotidiana, tal como a escola tradicional costuma fazer com alunos de primeira viagem.

O elefantinho de Kipling também é vítima não apenas de cerceamento moral como também se torna alvo da violência familiar. Cansado de apanhar, por conta da sua imensa curiosidade, e de náo encontrar o que deseja, resolve partir sozinho em busca das respostas sonegadas pela família. No retorno à casa, o "filho do elefante" está não apenas mais sábio, como mais fortalecido, e aplica em toda a família, de um modo bastante cruel, as liçôes que aprendeu 
no mundo lá fora. Aprofundemos-nos, então, nessa fábula de Kipling que não é tão conhecida quanto o romance de Lewis Carroll.

De início, já existe um estranhamento no universo fabuloso de Kipling, uma vez que a selva parece mais selvagem do que nunca para o curioso e frágil elefantinho, que é constantemente espancado pelos seus "queridos familiares" a cada nova pergunta que se propóe a fazer. $\mathrm{O}$ motivo de tanto espancamento, a priori, é atribuído à sua "curiosidade insaciável” (KIPLING apud BLOOM, 2003, p. 87), expressão continuamente repetida na fábula para enfatizar o perfil do protagonista; contudo, paira no ar uma outra motivação, que seria o desconhecimento das respostas por parte de todos os familiares, que optam pela ignorância física no lugar de confessarem uma ignorância intelectual.

De igual modo, os vínculos familiares estão dissolvidos, uma vez que os pais do elefantinho náo possuem uma presença real naquele ambiente, aparecendo apenas como referência no discurso do narrador. São os animais de outras espécies, chamados de "tios" e "tias" - avestruz, girafa, babuíno e hipopótamo - os responsáveis pela educação do jovem paquiderme. Há de imediato uma associação desse ambiente ao universo escolar, que assume o papel de "segunda casa" da criança, assimilando, inclusive, as mesmas medidas educativas usadas no ambiente familiar autoritário e repressivo: os castigos físicos que eram comumente aplicados como estratégia de "domesticação" do alunado. A autoridade dos pais era transmitida à escola, assim como certo vínculo familiar se traduzia na adoção de determinadas formas de tratamento aplicadas apenas no contexto hierárquico, e não no plano afetivo.

No caso de Kipling, de acordo com sua biografia Something of Myself, embora tendo nascido em Bombaim (Índia), era filho de pais ingleses. Com o propósito de educá-lo nos moldes pátrios, os pais deixaram-no, ainda pequeno, sob os cuidados de uma pequena instituição escolar na Inglaterra, e retornaram para a Índia. O escritor permaneceu durante seis anos como interno nessa escola - uma pequena casa responsável pela instrução de crianças - para ser alfabetizado e instruído de acordo com os padróes ingleses, uma vez que, até aquele momento, as referências de Kipling eram as suas aias indianas. O contato inicial com a escola inglesa evidenciava, de imediato, o contraste entre a sua cidade natal e o ambiente frio e austero de Portsmouth, para onde fora levado. 
As primeiras memórias escolares do escritor, além de marcadas pela brusca separação da família, revelam também momentos ainda mais obscuros, quando narra os castigos corporais aos quais era submetido na tal escola por ele denominada de "Casa da Desolação".

Houve então um país escuro e uma sala fria e mais escura e, junto a uma das paredes, havia uma mulher branca preparando fogo e eu chorei de pânico, pois nunca tinha visto uma lareira. Então veio logo outra pequena casa que cheirava a aridez e vazio, e o adeus de meu pai e de minha mãe pela madrugada, quando me disseram que eu tinha que aprender logo a ler e escrever para que eles pudessem me enviar cartas e livros. (...) Eu nunca antes tinha ouvido falar do inferno, mas ali me incutiram todos os seus terrores.(...) Eu mesmo era surrado regularmente. A mulher tinha um só filho, de doze ou treze anos (...). Eu representava para ele um prazer verdadeiro, pois logo depois que sua mãe já tinha acabado comigo num dia, ele (dormíamos no mesmo quarto) me pegava e completava a surra. (KIPLING, 2008, p. 5-6)

O ensino baseava-se, portanto, num rigor moral e religioso, e era imposto a partir de medidas disciplinares pautadas no castigo e na privação. A cultura do medo, seja do inferno ou da próxima surra, regulava os comportamentos no ambiente escolar e incutia uma submissão que não admitia questionamentos por parte da criança. O discurso da suposta autoridade era permeado, na verdade, pelo autoritarismo. Kipling também revela que essa estrutura coercitiva da escola era tão imperiosa que impedia que a criança denunciasse os maus-tratos à família, por acreditar no poder absoluto e inquestionável do adulto e de determinadas instituiçóes sociais.

Muitas vezes, depois desse tempo, minha amada tia me perguntou por que eu nunca havia contado a ninguém como me tratavam. As crianças reclamam quase táo pouco como os animais, e é porque aceitam o que lhes ocorre como algo eternamente estabelecido. Também porque as crianças maltratadas 
fazem uma ideia muito clara do que lhes pode acontecer se revelam os segredos de uma prisão antes de sair dela. (KIPLING, 2008, p. 15)

A comparação entre as crianças e os animais, na sua singeleza e na sua domesticação, aproxima o universo da fábula do mundo infantil, mas Kipling resolve não fabular em torno de um mundo do "faz de conta", mas transformar o universo fabulativo em espelho do mundo dos homens, denunciando toda a sua violência e autoritarismo.

O sociólogo Richard Sennett, ao analisar o conceito de autoridade que vigora nas instituições sociais, começa sua reflexão a partir do ambiente familiar, destacando a dubiedade da palavra "vínculo", que tanto pode ser ligação quanto servidão. Mais uma vez, estamos diante do dilema do cão da fábula de La Fontaine. Ao se deixar "domesticar", o animal passa a dispor de um vínculo com o homem, o que lhe traz algum benefício, mas, por outro lado, faz dele eternamente cativo da vontade de outrem. De igual modo, os laços que nos prendem aos liames sociais nos concedem uma ideia de segurança, de amparo e proteção, mas podem ser também os principais instrumentos do cerceamento da liberdade.

A palavra "vínculo" tem um duplo sentido. É uma ligação, mas é também, como em "servidão", um limite imposto. Nenhuma criança poderia evoluir sem o sentimento de confiança e amparo que provém da crença na autoridade de seus pais; no entanto, na vida adulta, muitas vezes se teme que a busca dos benefícios emocionais da autoridade transforme as pessoas em dóceis escravos.

Similarmente, a fraternidade é uma ligação entre adultos que pode facilmente transformar-se em um pesadelo: pode provocar uma agressão hostil contra as pessoas de fora ou uma luta interna sobre quem "realmente" faz parte do grupo. A solidão parece ser uma falta de ligação e, por conseguinte, uma falta de limites. Mas pode ser táo dolorosa que as pessoas se comprometem às cegas com um casamento, um emprego ou uma comunidade, embora descubram que, em meio às demais continuam 
sozinhas. O ritual unifica, mas é um sentimento de união estranho, porque desaparece no instante em que o ritual termina. (SENNETT, 2012, p. 14)

$\mathrm{Na}$ fábula de Kipling, a saída do elefantinho do ambiente repressivo dos "queridos familiares" - termo que soa ironicamente na fábula - significa uma ruptura com os vínculos autoritários, que, de início, pareciam necessários à sua sobrevivência e proteção. Cansado das negativas e das surras, o personagem conclui que as respostas de que necessita só poderão ser encontradas a partir de uma vivência com o mundo real, fora das restriçóes do espaço familiar.

A segurança de um ambiente aparentemente acolhedor é anulada a partir do cativeiro, físico e/ou intelectual, e do uso de medidas repressivas e repressoras. Assim sendo, tal como o lobo de La Fontaine, o elefantinho de Kipling não aceita as regras do jogo e segue em sua busca pessoal pela liberdade de conhecimento. Solitariamente, se submete ao mundo, assumindo os riscos, a insegurança e as incertezas que sua busca pode provocar.

A viagem do pequeno elefante é, portanto, uma forma de livrar-se da opressão que, sob a máscara dos fins educativos, passa a impor limites à curiosidade e à inteligência. $\mathrm{O}$ ambiente repressivo não favorece a aprendizagem, mas unicamente pretende incutir um modelo de saber pré-estabelecido. Ainda assim, o personagem vai descobrir que fora do ambiente familiar a opressão continua, mas há alianças que podem resultar em benefícios para a sobrevivência. Apesar de ser quase devorado pelo crocodilo, o protagonista da fábula vivencia uma experiência transformadora e encontra a resposta para a sua principal indagação: "o que o crocodilo come no jantar?".

A vitória sobre a dúvida é simbolizada pela aquisição da tromba, que passa a ser um instrumento eficaz tanto de execução quanto de extinção da violência, servindo também de auxílio à adaptação do jovem animal aos desafios da vida selvagem, ao conquistar algumas vantagens que o tornam singular, forte e temido naquele ambiente.

O perfil reflexivo da fábula, resgatado por Carroll e Kipling, soa em nosso tempo como um discurso subversivo. Na contemporaneidade, vivemos aparentemente num ambiente democrático e somos indivíduos livres para expressar nossas opiniôes, porém, essas opiniôes são cerceadas pelo discurso do "politicamente correto". O próprio termo é difícil de ser definido como algo 
uniforme, uma vez que cada indivíduo tem uma ideia distinta do que é ou não é correto na vida em sociedade, em geral, mas, primordialmente, existem os discursos velados (ou não) que revelam os preconceitos que sobrevivem no âmago da sociedade, em especial no que se refere às minorias. É difícil tratar da liberdade de escolha e da livre expressão da vontade numa sociedade marcada pelo drama de uma dicotomia, que Zigmunt Bauman descreveu como uma fórmula difícil de equalizar: quanto mais liberdade, menos segurança/ quanto mais segurança, menos liberdade.

A promoção da segurança sempre requer o sacrifício da liberdade, enquanto esta só pode ser ampliada à custa da segurança. Mas segurança sem liberdade equivale à escravidão (e, além disso, sem uma injeção de liberdade, acaba por ser afinal um tipo muito inseguro de segurança); e a liberdade sem segurança equivale a estar perdido e abandonado (e, no limite, sem uma injeçáo de segurança, acaba por ser uma liberdade muito pouco livre). Essa circunstância provoca nos filósofos uma dor de cabeça sem cura conhecida. Ela também torna a vida em comum um conflito sem fim, pois a segurança sacrificada em nome da liberdade tende a ser a segurança dos outros; e a liberdade sacrificada em nome da segurança tende a ser a liberdade dos outros. (BAUMAN, 2003, p. 24)

Tudo indica que estamos agora num tempo em que não basta escolher o caminho da liberdade, tal como foi a escolha do lobo da fábula. Na sociedade atual, o indivíduo necessita também da segurança oferecida pelo discurso do cão e, igualmente, da inserção num grupo mais forte que possa oferecer algum tipo de proteção, um laço afetivo e/ou alguma vantagem material, ainda que mínimos, em troca da liberdade.

Relendo a fábula de La Fontaine à luz de Bauman, ficamos hoje divididos entre a escolha do lobo (liberdade) e o discurso convincente do cão (segurança). Sobretudo, a própria necessidade de inserção nos padróes sociais, pelo medo da solidão ou da exclusão na sociedade globalizada, torna-se algo primordial ao indivíduo. As conexóes e vínculos, ainda que frágeis e sujeitos a constantes rupturas, assumem uma dimensão mais sedutora do que a liberdade, que hoje pa- 
rece um preço muito alto a se pagar para ser apenas um lobo solitário e faminto.

Se os problemas do mundo dos adultos relacionados à equação liberdade x segurança estão caminhando para um momento de tensôes e conflitos na contemporaneidade, questóes como essas também vão permear o universo infantil, na medida em que há uma discussão acerca dos "limites" e da "falta de limites" que o sistema familiar e o educativo impóem ou deixam de impor em relação às crianças. Na concepção mais genérica de alguns discursos, muita liberdade produz indivíduos indolentes, muita segurança e repressão formam seres medrosos e limitados. Questionar a autoridade do universo adulto, como vimos nos personagens das fábulas de Carroll e Kipling, pode ser para alguns uma faca de dois gumes.

Diante do fato, a tendência de alguns escritores da literatura infanto-juvenil atual parece ser a mesma adotada no séc. XIX: a de se colocar como um filtro entre a criança e o texto original ou a de conduzir a literatura pelo caminho das aplicaçôes ou explicaçôes didáticas. Alguns autores se tornam autorreferenciais ou limitadores, na medida em que já dizem o que o suposto leitor poderia deduzir por ele mesmo ou procuram fazer um certo direcionamento na leitura para valorizar um aspecto pré-determinado.

Esse crivo passa também a nortear as adaptações dos clássicos para a linguagem infantil, fazendo com que alguns adaptadores "limpem" o texto de assuntos e reflexóes que possam ser polêmicas ou que tratem de certas questóes consideradas tabu pela sociedade. Ainda hoje, muitos adotam o recurso da adaptação dos clássicos com o propósito de facilitar a compreensão das crianças, mas seguem podando a ideia original daquilo que julgam inadequado. Para alguns, uma fábula como "O filho do elefante" soaria de maneira muito violenta e tocaria num ponto que incomoda bastante algumas pessoas, que é o questionamento da autoridade dos adultos.

As adaptações dos clássicos falam por suas lacunas. Em 2012, por exemplo, o governo argentino, a partir de uma parceria entre o Instituto Internacional de Planeamiento de la Educación (IIPE) e a Unesco, resolveu distribuir gratuitamente para as escolas de formação primária uma adaptação da fábula "O filho do elefante". As propostas didáticas parecem encontrar na literatura algo subversivo e estáo quase sempre prontas a moldar o texto ao pensamento das crianças ou, o que parece mais sério, a moldar o pensamento da criança aos contextos vigentes. 
Adaptada para fins didáticos, a fábula de Kipling sofreu uma série de cortes, principalmente nas cenas de embate entre o protagonista e a família. A cena final da fábula foi absolutamente podada pelos adaptadores e, tal como a proposta didática de Samaniego, parece ter a intenção de corrigir a história original do que poderia ser considerado violento ou inadequado para as crianças. Vejamos o final da história de Kipling, segundo a adaptação didática argentina.

Em certo entardecer, [o elefantinho] chegou a sua casinha, dobrou a tromba para cima e disse:

- Como estão todos?

Alegraram-se muito ao vê-lo, mas disseram em seguida:

- Você merece um castigo por ter ido táo longe e pelo que fez com seu nariz.

- Não!- exclamou o elefantinho e, desdobrando a tromba, com um par de empurróes, deixou estendidos no chão muitos de seus irmãos. (KIPLING, 2012, p. 22)

Crianças tendem a fazer perguntas desconcertantes e a questionar determinados valores sociais sem pensar se sua curiosidade é adequada ou não à ética dos adultos. No texto original de Kipling, não há um motivo justo para os familiares espancarem o pequeno elefante, a não ser por conta de sua curiosidade insaciável. $\mathrm{Na}$ adaptação argentina do texto de Kipling, os familiares fazem referência a um "castigo" e buscam justificar a atitude pelo fato de o elefantinho ter ido táo longe de casa e de ter "estragado" o nariz. Tal justificativa busca moralizar a forma de tratamento da família, o que inexiste no original.

Para efeito comparativo, vale cotejar a adaptação com a tradução que José Antonio Arantes fez para a versáo brasileira da coletânea de Harold Bloom.

Numa tarde escura, [o elefantinho] voltou à casa dos familiares queridos e, enrolando a tromba, perguntou:

- Como vão?

Ficaram muito contentes de vê-lo e logo disseram:

- Venha cá para ser espancado por sua curiosidade insaciável.

- Ora! - exclamou o filho do elefante. - Não acho que saibam o 
que é espancar. Mas eu sei, e vou lhes mostrar.

Então desenrolou a tromba e pôs dois irmãos queridos de pernas para o ar. (...)

Então o mau filho do elefante espancou todos os queridos familiares por bastante tempo, até ficarem muito ardidos e bastante surpresos. (KIPLING apud BLOOM, 2003, p. 98)

A suavização da fábula "inadequada” de Kipling parece ser mais um dos atalhos didáticos para ajustar o discurso literário às demandas moralizantes da sociedade. Mas há uma questão importante: quem pode definir se esse ou aquele modelo é mais adequado sem um estudo sistemático da importância dessas histórias na formação das crianças e sem avaliar como as crianças lidam com determinados assuntos? Como analisar a validade de uma fábula original sem que a criança possa lê-la na íntegra?

\section{Confabulações literárias: conclusão}

Teresa Colomer, analisando os principais personagens das histórias infanto-juvenis, percebe que a figura do animal é uma das mais utilizadas para fazer a transposição dos dramas reais para o plano das ideias, de maneira que se torna um importante instrumento de reflexão da criança acerca das questóes impactantes da vida em sociedade.

A figura do animal (e especialmente de alguns deles, como os ursos ou todo tipo de roedores, dado que suas características e conotaçôes parecem favorecer a identificação infantil) é um recurso utilizado frequentemente para criar certa distância entre o leitor e uma história especialmente transgressora das normas sociais ou demasiado dura afetivamente. Desta maneira, o impacto de acontecimentos, como a morte dos personagens ou a excitação produzida pela vulnerabilidade das normas de conduta, será menor, já que os atores não são humanos. (...) Também fica claro que os animais podem cometer açôes terríveis e proibidas aos humanos, como planejar a caça de outros animais ou rebelar-se contra os humanos adultos. (COLOMER, 2007, p. 56) 
A avaliação de Colomer a respeito da transposição dos dramas reais para o universo da fábula é positiva, na medida em que a criança consegue lidar melhor com algumas questóes polêmicas quando estão sob o invólucro da puerilidade do universo animal. Assim sendo, a literatura torna-se um discurso essencial na medida em que passa a encenar, projetando na imaginação, as sombras do nosso mundo. A arte, portanto, desloca o homem de seu universo cotidiano, a fim de que ele possa enxergar com mais clareza algumas questóes importantes, muitas vezes não percebidas quando se está mergulhado na vivência da situação.

Diante de um mundo permeado pela violência, há uma tendência em falsear a realidade e de fazer da literatura um refúgio, um passatempo para distrair as pessoas das agruras da vida. A superproteção da criança, com a intenção de defendê-la de um mundo no qual está inserida, a fragiliza. Levantam-se cercas e muros do lado de fora, a fim de que, na proteção desse abrigo, a infância esteja em plena segurança.

Mas há sempre perguntas sem respostas, verdades maquiadas e, o mais significativo, a perda da liberdade. Ao agirem como filtros da "verdade", certas visóes moralizantes presentes em algumas adaptaçóes das obras literárias acabam reafirmando os valores instituídos na sociedade, que são os mesmos que se valem do autoritarismo para impor a violência que pensávamos ter deixado do lado de fora.

$\mathrm{Na}$ sociedade individualizada e individualizante, cada sujeito, valendo-se da sua liberdade de expressão, está fadado a chocar-se com os limites do outro e, principalmente, com os limites de determinados pensamentos e açóes do grupo social do qual faz parte ou de outros grupos sociais que o excluem. Por outro lado, as pessoas tendem a ficar mais restritas aos problemas individuais, deixando de trazer a público questóes importantes, que precisam ser debatidas e solucionadas no seio da sociedade, tal como afirma Bauman ao criticar a Ágora contemporânea (BAUMAN, 2008, p. 256).

Guardar as indagaçôes de homens e crianças em suas cercas individuais parece ser um isolamento insuportável num mundo cada vez mais hedonista, pouco disposto a discutir questôes tấo sérias e profundas, mais propenso a romantizar tudo, a amenizar tudo, inclusive os livros e a literatura, em busca de um ideal de conciliação. A formação do leitor exige a leitura crítica de textos de boa qualidade, a fim de oferecer um campo aberto às reflexôes e não um universo prescritivo, de recomendaçóes pouco afinadas à realidade na qual vivemos. 
A arte e a literatura, como recursos especificamente humanos, têm procurado expressar, ao longo das eras, os sentidos do ser, seus dramas, desejos e sentimentos a respeito do estar no mundo, como um ensaio para a vida e sobre a vida e, muitas vezes, como reinvenção da vida. Durante essa longa jornada, obras e homens foram vetados, criticados, extirpados, excluídos e neutralizados por algum motivo, em geral por questôes políticas, morais e religiosas. Palavras exercem um imenso poder, e discursos parecem ser, em alguns contextos, mais influentes que o uso da força, como as fábulas clássicas quiseram nos mostrar.

A literatura, porém, em sua essência mais profunda, continua a falar às crianças inteligentes de todas as idades. A capacidade do homem de fabular é um modo de ensinar a lidar com emoçóes e conflitos, consigo mesmo e com o outro, a partir da reflexão e de uma leitura catártica da vida. Mas, para que o texto literário seja apreciado com total liberdade e profundidade, é preciso que deixemos de levá-lo sempre à coleira, como as pessoas fazem com os animais de estimação, com medo de que ele definitivamente nos escape.

\section{Referências}

ANDRADE, Carlos Drummond de. Antologia poética. Rio de Janeiro: Record, 2005. BAUMAN, Zigmunt. A sociedade individualizada: vidas contadas e histórias vividas. Trad. José Gradel. Rio de Janeiro: Zahar, 2008.

- Comunidade: a busca por segurança no mundo atual. Trad. Plínio Dentzien. Rio de Janeiro: Jorge Zahar, 2003.

BLOOM, Harold. Contos e poemas para crianças extremamente inteligentes de todas as idades. 2 vol. Tradução de José Antonio Arantes. Rio de Janeiro: Objetiva, 2003.

COLOMER, Teresa. Andar entre livros: a leitura literária na escola. Trad. Laura Sandroni. São Paulo: Global, 2007.

ESOPO. Fábulas de Esopo com aplicaçóes morais a cada fábula. Paris: Typographia de Pillet Fils Ainé, 1848.

KIPLING, Rudyard. El hijo del elefante. Adaptado por María Elena Cuter; ilustrado por Alejandro First. Ciudad Autónoma de Buenos Aires: Instituto Internacional de Planeamiento de la Educación IIPE-Unesco, 2012.

. Something of myself: for my friends known and unknown. Edinburgh;

Great Britain: Wildside Press LLC, 2008. 
LA FONTAINE, Jean de. Oeuvres completes de La Fontaine: fables. Chez Lefèvre Libraire: Paris, 1818.

. Fábulas escolhidas. Org. de Francisco Manoel do Nascimento. Paris: Oficina de Celot, 1815.

SAMANIEGO, Félix María. Fabulas em verso castellano para uso del Real Seminario Bascongado. Valencia: Benito Monfort, 1781.

SENNETT, Richard. Autoridade. Trad. Vera Ribeiro. 2 ed. Rio de Janeiro: Record, 2012.

VIDIGUEIRA, Manoel Mendes da. Prefácio. In: ESOPO. Fábulas de Esopo. Traduzidas da Língua Grega com aplicaçóes morais a cada fábula por Manoel Mendes da Vidigueira. Lisboa: Typografia Rollandiana, 1791. (Com licença da Real Mesa da Comissão Geral sobre o Exame e Censura dos Livros).

\title{
DOMESTICATED FABLES: THE POLITICAL AND MORAL ROLE OF THE SCHOOL IN DIDACTICAL ADAPTATIONS OF LITERARY TEXTS
}

\begin{abstract}
How were the fables of classical authors such as Aesop and La Fontaine undergoing modifications and adaptations over time until they become a moralizing model for children in didactic manuals from the 19th century? This study aims to analyze this process of adaptation of the fable to didactic purposes and reflect on the work of Rudyard Kipling: “The Elephant's Child”, as a way of thinking about the child's tensions before the unknown and the relations of authority and authoritarianism that exist in the adult world.
\end{abstract}

KEYWORDS: fables; Rudyard Kipling; adaptation.

Recebido em: 30/10/2015

Aprovado em: 01/02/2016 